Łukasz Kutyło

Instytut Socjologii UŁ

\title{
Religijne odniesienia w propagandzie wojennej Analiza zjawiska
}

\section{Wprowadzenie}

Przedmiotem moich rozważań, których wyniki prezentuję w poniższym tekście, stały się odniesienia religijne w propagandzie wojennej. Analizą objąłem plakaty oraz kartki pocztowe tworzone w trakcie I i II wojny światowej, wojny domowej w Rosji oraz wojny polsko-bolszewickiej. Niemal wszelkie odniesienia religijne, które w nich występowały, miały swe źródło w tradycji chrześcijańskiej. To rodzi pytanie, na które trudno odpowiedzieć w sposób jednoznaczny. Jak chrześcijaństwo, jako religia nakazująca troskę o innych, której twórca - Jezus Chrystus - był przez proroka Izajasza ${ }^{1}$ postrzegany jako Książę Pokoju (Iz. 9,6), mogła stanowić inspirację dla propagandy wojennej? Warto pamiętać, że w zasadzie wszystkie religie uniwersalistyczne cechuje schizofreniczne pęknięcie. $Z$ jednej strony wymagają one od swych wyznawców miłowania bliźnich. Z drugiej zaś, formułują pewne uzasadnienia dla przemocy wobec nich oraz stanowią natchnienie dla tych, którzy do walki nawołują. Thomas Hobbes wstrząśnięty tym, jakie spustoszenie poczyniły w Europie wojny religijne, stwierdził w Lewiatanie ([1651] 2005), że ludzie dopuszczali się podczas nich czynów, których nie popełniłoby żadne zwierzę. Zdaniem angielskiego myśliciela działo się tak, gdyż wierzyli w Boga.

${ }^{1}$ Mam tu na myśli oczywiście interpretację chrześcijańską, a nie żydowską. 
To pęknięcie cechujące religie uniwersalistyczne skłoniło mnie do postawienia pytania, które stało się punktem wyjścia refleksji. Brzmiało ono następująco: $\mathbf{w}$ jaki sposób na użytek propagandy wojennej instrumentalizuje się religię? Zdefiniowanie problemu w ten sposób sprawiło, że na wstępie niezbędne wydały się rozważania nad znaczeniem terminów: religia oraz instrumentalizacja religii.

\section{Terminologiczne i metodologiczne aspekty analizy}

W pierwszej kolejności przedmiotem uwagi uczyniłem pojęcie religii. Nie ma wśród socjologów zgody, jak ów termin należy rozumieć. W literaturze przedmiotu najczęściej używana bywa typologia zakładająca istnienie definicji substancjalnych oraz funkcjonalnych (Berger 1971). Różnice istniejące między nimi wyjaśnił Karel Dobbelaere stwierdzając:

Definicje substancjalne mówią o tym, czym jest religia. Natomiast definicje funkcjonalne mówią jakie jest działanie religii i jakie są konsekwencje tego działania w odniesieniu do kontekstu strukturalnego religii (Dobbelaere [1974] 2003: 139).

Pierwsze z nich nawiązują do tradycji weberowskiej². Substancjalną w swej istocie definicję sformułował m.in. Peter Berger, który w pracy zatytułowanej Święty Baldachim. Elementy socjologicznej teorii religii ([1967] 2005) wskazał, iż religia jest „ludzkim przedsięwzięciem, które ustanawia święty kosmos" (Berger 2005: 57). Dalej sprecyzował samo pojęcie świętości. Pod terminem tym rozumiał „jakość tajemniczej i budzącej grozę siły, odmiennej od człowieka, a jednak związanej z nim, co do której jest się przekonanym, że tkwi w pewnych obiektach doświadczenia" (Berger 2005: 57). W definicjach substancjalnych nacisk kładzie się zatem na treść pojęcia. Zasadniczą rolę odgrywa tu rozróżnienie na rzeczywistość immanentna, empiryczną oraz transcendentna, znajdującą się poza ludzkim doświadczeniem. Nieco inny charakter mają definicje funkcjonalne. Nawiązują one do durkheimowskiego rozumienia religii. Ów klasyk socjologii definiował ją w sposób następujący:

${ }^{2}$ Należy jednak pamiętać, że Max Weber nigdy explicite nie sformułował definicji religii. We wstępie do rozdziału V Gospodarki $i$ społeczeństwa autor stwierdził: „Definicja tego czym 'jest' religia, nie może otwierać rozważań takich, jak te zawarte w tym rozdziale, mogłaby je ewentualnie zamykać" (Weber [1922] 2002: 318). Owej definicji nie ma jednak ani na końcu owego rozdziału, ani w żadnym innym miejscu. 
Religia jest systemem powiązanych ze sobą wierzeń i praktyk odnoszących się do rzeczy świętych, to znaczy rzeczy wyodrębnionych i zakazanych, wierzeń i praktyk łączących wyznawców w jedną wspólnotę moralną zwaną kościołem (Durkheim [1912] 1990: 41).

Definicję funkcjonalną zaproponował także John M. Yinger. Badacz ten uważał, że religię można określić jako

zespół przekonań i praktyk, za pomocą których określona grupa stawia czoło [...] wielkim problemom ludzkiego życia. Jest to odmowa kapitulacji w obliczu śmierci, klęsk i niepowodzeń, niezgoda na to, by wrogie nam siły zniszczyły sieć naszych ludzkich powiązań (Yinger 1957: 17, cyt. za Dobbelaere [1974] 2003: 140).

Funkcjonalne rozumienie religii koncentruje się zatem na roli, jaką odgrywa ona w społeczeństwie ${ }^{3}$.

Najbardziej przekonujące według mnie podejście, które wziąłem pod uwagę w swej analizie, zaproponowała francuska badaczka Danièle Hervieu-Léger. W podejmowanych rozważaniach próbowała przezwyciężyć dychotomię na substancjalne i funkcjonalne rozumienie religii. W pracy zatytułowanej Religia jako pamięć ([1993] 2007) stwierdziła, że we współczesnym świecie „pierwiastek religijny” uległ rozproszeniu, przejawia się $\mathrm{w}$ wielu różnych obszarach społeczeństwa. Pojawia się zatem potrzeba zdefiniowania zjawisk stricte religijnych. W przeszłości ich identyfikacji niejednokrotnie dokonywano poprzez odwoływanie się do wymiaru sacrum. W dzisiejszych czasach sytuacja jest bardziej skomplikowana, doświadczenie sakralności pozostaje bowiem charakterystyczne także dla zjawisk dalekich od religijności. Jak stwierdziła autorka:

doskonałe pokrywanie się dwóch wymiarów - sakralności i religijności - jest wyobrażalne idealno-typicznie wyłącznie w społeczeństwach tradycyjnych, w których religia stanowi jedyny kod sensów. Inaczej dzieje się w nowoczesnym społeczeństwie, które mnoży sposoby wytwarzania sensu, powodując jednocześnie ich coraz dalej posunięte rozproszenie (Hervieu-Léger 2007: 150).

${ }^{3}$ Z definiowaniem wskazanego terminu wiążą się oczywiście pewne kontrowersje, które warto rozważyć. Dotyczą one przede wszystkim funkcjonalnego rozumienia religii. Zdaniem K. Dobbelaere, ta durkheimowska tradycja pojmowania religii z co najmniej trzech powodów wydaje się dyskusyjna. Po pierwsze, definiuje się ją jako funkcjonalną dla określonej grupy. Po drugie, trudno jest mówić o jakichkolwiek świeckich alternatywach względem wiary, gdy wszystko, co spełnia funkcję jest religią. Po trzecie, skoro człowiek pozostaje $\mathrm{z}$ definicji istotą religijna, jak zakłada owa tradycja, to każdy sposób „przezwyciężania” fundamentalnych dla niego problemów ma charakter religijny (Dobbelaere 2008: 73-74). 
Religijne odniesienia w propagandzie wojennej. Analiza zjawiska

Sakralność stanowi zatem jedną z możliwych modalności organizowania zbiorowych znaczeń, w odniesieniu do których jednostki i grupy społeczne nadają sens swojej własnej egzystencji.

Autorka zasugerowała więc wprowadzenie rozróżnienia na wierzenie oraz religię. Pod pierwszym pojęciem należy rozumieć

zbiór przekonań indywidualnych i zbiorowych, które nie podlegają weryfikacji, eksperymentom czy - w szerszym ujęciu - nie poddają się charakterystycznym dla wiedzy sposobom poznania i sprawdzania, ale które służą nadawaniu sensu i spójności subiektywnemu doświadczeniu tych, którzy uznają je za własne (Hervieu-Léger 2007: 105).

Tak pojmowane wierzenie obejmuje zatem nie tylko ideowe przedmioty przekonań (wierzenia sensu stricto), ale też praktyki, języki, gesty, a także spontaniczne odruchowe zachowania. Religia natomiast to jedna z form wierzenia. Autorka definiuje to pojęcie w sposób następujący:

ideologiczny, praktyczny i symboliczny wyznacznik, dzięki któremu tworzy się, utrzymuje, rozwija i kontroluje (indywidualna i zbiorowa) świadomość przynależności do pewnej szczególnej linii wyznaniowej (Hervieu-Léger 2007: 119).

Aby można było uznać jakieś wierzenie za religię, spełnione muszą być określone warunki. Ta forma wierzenia odwołuje się bowiem do pewnej przeszłości, realistycznej bądź całkowicie wykreowanej, pozostaje twórczym „kodem sensów” tradycji. Religia stanowi swego rodzaju linię wyznaniową, ów „łańcuch powiązań”, dzięki któremu jednostkowe wierzenie przeistacza się we wspólnotowe. Zapewnia ciągłość między przeszłością a teraźniejszością. Zawiera w sobie perspektywę przyszłości.

Z postawionymi na wstępie pytaniami wiąże się także kwestia instrumentalizacji religii, a więc stosowania jej $\mathrm{w}$ tych kontekstach społecznych, które z wiarą czy sacrum nie mają nic wspólnego. Problem ten wpisuje się w szerszą dyskusję, dotyczącą zjawiska określanego mianem deprywatyzacji religijności. Rozważania nad tym fenomenem, obszernie zresztą analizowanym w literaturze przedmiotu (por. Casanova [1994] 2005; Habermas 2012), przesunęły punkt ciężkości refleksji na zagadnienia związane z publiczną aktywnością religii. Punktem wyjścia całej dyskusji była rewolucja islamska w Iranie w roku 1979 (Corm 2007). Zdecydowana większość autorów przedmiotem swych rozważań uczyniła zatem zjawiska współczesne, wkomponowujące się zazwyczaj w to, co powszechnie określa się mianem fundamentalizmu religijnego (por. Kepel 2010). Trudno jednak zgodzić się z takim podejściem. W rzeczywisto- 
ści bowiem zjawisko deprywatyzacji odnosi się do dwóch kwestii, które zdefiniować można jako: instrumentalizację religii do celów politycznych oraz instrumentalizację polityki do celów religijnych. Zainteresowanie większości badaczy wzbudził drugi ze wskazanych procesów. W moim odczuciu jednak oba zjawiska są tak ściśle ze sobą związane, że często trudno odróżnić, z którym z nich mamy w danej sytuacji do czynienia. Trzymając się jednakże tego rozróżnienia, przedmiotem refleksji uczyniłem pierwszy z omawianych procesów. Nie jest on zresztą czymś wyjątkowym. Nie ogranicza się do czasów współczesnych. Religia pozostaje systemem znaczeń, który łatwo daje się zastosować w różnych okolicznościach historycznych, nawet w oderwaniu od swego pierwotnego zaplecza. Ta wskazywana przeze mnie zbieżność obu procesów pozwala na opisanie zjawiska instrumentalizacji religii do celów politycznych za pomocą koncepcji wypracowanych w odniesieniu do fenomenu deprywatyzacji.

Interesującą teorię $w$ tym względzie zaproponował Peter Beyer (por. Beyer 2005). Autor ten wyszedł od założeń analizy funkcjonalnej opracowanej przez Niklasa Luhmanna. Niemiecki badacz uznał, że przedmiotem rozważań należy uczynić orientacje, które w obrębie podsystemów odnoszą się do całego systemu, do podsystemów wewnątrz środowiska tego systemu i do danego podsystemu. Te orientacje to funkcja, działanie oraz refleksja (Luhmann [1982] 2007: 246). P. Beyer skoncentrował się na dwóch pierwszych. Za N. Luhmannem, funkcję określił mianem „czystej komunikacji”, odnoszącej się do transcendencji oraz tych zjawisk, które instytucje religijne zastrzegają wyłącznie dla siebie, decydujących o ich autonomii we współczesnym społeczeństwie. Przez działanie natomiast rozumiał „używanie" religii do rozwiązywania problemów społecznych, zwłaszcza zaś tych, które ignorowane są przez wszystkie pozostałe obszary funkcjonalne. $\mathrm{W}$ opinii $\mathrm{P}$. Beyera te problemy społeczne, nazywane przez niego rezydualnymi, to przede wszystkim ubóstwo ekonomiczne, ucisk polityczny, rozpad rodziny czy degradacja środowiska naturalnego (Beyer 2005: 144). Moim zdaniem, to działanie społeczne, które badacz uczynił przedmiotem swego zainteresowania, odnosi się także do sytuacji, gdy religia ulega instrumentalizacji w ramach propagandy wojennej. Jako pewien system znaczeń znajduje ona wówczas zastosowanie w procesie mobilizacji społeczeństwa. Sytuację opisaną przez P. Beyera od tej, która stała się przedmiotem mojej analizy, odróżnia odmienny poziom autonomii podsystemu religijnego. $\mathrm{W}$ przypadku deprywatyzacji analizowanej przez tego badacza ów podsystem cechuje się dużym stopniem 
Religijne odniesienia w propagandzie wojennej. Analiza zjawiska

niezależności, jego celem zaś jest narzucenie innym obszarom funkcjonalnym (bądź włączenie $\mathrm{w}$ ich struktury) perspektywy religijnej. W sytuacji opisywanej przeze mnie, podsystem religijny ulega natomiast podporządkowaniu podsystemom strukturalnie silniejszym (w tym przypad$\mathrm{ku}$ - polityce). Traci tym samym swoją autonomię. Innymi słowy, przez instrumentalizację należy rozumieć "używanie" religii przez inne obszary funkcjonalne do rozwiązywania generowanych $w$ ich ramach problemów.

Zjawisko instrumentalizacji religii postanowiłem rozpatrzyć na przykładzie propagandy wojennej i stosowanych $w$ jej ramach strategii, zorientowanych na mobilizację społeczeństwa. Skoncentrowałem się na określonych wydarzeniach, w tym na I i II wojnie światowej, wojnie domowej w Rosji oraz wojnie polsko-bolszewickiej. Przedmiotem analizy uczyniłem trzy kartki pocztowe (wszystkie pochodzące z okresu I wojny światowej) oraz dwadzieścia trzy plakaty. Ich dobór miał charakter celowy. Wszystkie znalazłem w Internecie. Oś, wokół której koncentrowało się badanie, wyznaczyły następujące pytania problemowe:

Pytanie I: Czy analizowane formy graficzne wprost zawierały elementy religijne, czy raczej odnosity się do nich pośrednio?

Biorąc pod uwagę szeroką definicję religii D. Hervieu-Léger, przyjętą w badaniu, musiałem uznać, że na niektórych plakatach tematyka i symbolika religijna będą prezentowane wprost, na innych zaś - w sposób pośredni. W tym drugim przypadku powinno się dać jednak zidentyfikować istnienie pierwiastka religijnego, metafizycznych odniesień, pewnej ciągłości między przeszłością a teraźniejszością.

Pytanie II: W jaki sposób tematyka i symbolika religijna byly prezentowane na analizowanych kartkach pocztowych i plakatach? Jakich środków używali autorzy do ich wyrażenia?

P. Beyer twierdzi, że ów proces „używania” religii do rozwiązywania problemów społecznych przyczynia się do ukształtowania bądź/i wzmocnienia tożsamości grupy, która $\mathrm{w}$ tym procesie uczestniczy. Ten pogląd odniosłem do podjętego przez siebie zagadnienia. Uznałem, że tematyka i symbolika religijna powinny znaleźć zastosowanie $\mathrm{w}$ budowie obrazu własnej grupy oraz zbiorowości, z którą jest ona w konflikcie. W sytuacji militarnej konfrontacji obie kategorie konstruowane są w sposób spolaryzowany, wojna sprzyja bowiem zjawisku wynoszenia własnej grupy ponad inne, przypisywania jej cech pożądanych w danych warunkach (męstwa, odwagi), a także dyskredytowaniu przeciwnika, opisywaniu go za pomocą diametralnie różnych obrazów czy słów. 
Pytanie III: Jaki cel przyświecał autorom decydującym się na wykorzystanie odniesień religijnych na swych kartkach pocztowych, plakatach?

Nurtowało mnie także to, jakie odczucia, emocje chcieli autorzy wywołać bądź jakich uniesień pragnęli uniknąć uwzględniając odniesienia religijne $\mathrm{w}$ swych pracach.

Pytanie IV: Jakie różnice dało się zaobserwować w analizowanych wytworach propagandy, tworzonych na użytek różnych konfliktów zbrojnych?

Zastanawiało mnie to, $\mathrm{w}$ jakim stopniu odniesienia religijne, używane w ramach propagandy wojennej, różniły się miedzy sobą. Czy w posterach tworzonych przez rosyjskich i niemieckich autorów pojawiały się te same wątki, obrazy? Czy plakaty opracowywane w trakcie II wojny światowej nawiązywały do tych, które powstawały w latach 1914-1918?

Dokonując analizy tematyki i symboliki religijnej obecnej na plakatach, próbując odpowiedzieć na postawione pytania, nie mogłem zapomnieć o kontekście historycznym i społecznym. Miałem świadomość, że pewne odniesienia religijne, dziś mogące wydawać się ekscentrycznymi, pozostawały w danych okolicznościach ważne dla grupy, do której je kierowano.

\section{Pierwsza wojna światowa}

Podczas I wojny światowej w propagandzie wojennej często stosowano odniesienia religijne. Wynikało to zapewne $z$ faktu, że ówczesne społeczeństwa europejskie nie były jeszcze tak zsekularyzowane, jak kilka dekad później. Brały to pod uwagę rządy państw zaangażowanych w konflikt, które próbowały uzasadnić prowadzenie działań zbrojnych odwołując się do religii. Z dzisiejszej perspektywy skuteczność tej taktyki pod wieloma względami wydaje się wątpliwa. Chrześcijanie stawali do walki ze swymi współwyznawcami z innych krajów. Ta sytuacja powinna rodzić wiele pytań. Dlaczego Bóg pozwala na to, aby jedni chrześcijanie walczyli przeciw innym? Dlaczego opowiada się po jednej stronie konfliktu (jak wskazywała na to propaganda wojenna)? Jak pogodzić pokojowe przesłanie tej religii z dramatem wojny, w której chrześcijanie brali udział? Te problemy stały nie tylko przed zwykłymi ludźmi, którzy zostali wrzuceni w wir konfliktu, ale również przed osobami realizującymi działania propagandowe.

Jak wykazała przeprowadzona analiza, dylemat ten w różny sposób próbowano rozwiązać. Jedną ze strategii daje się zaobserwować na kart- 
kach pocztowych z tamtego okresu. Widnieje na nich osoba Chrystusa. Poniżej przedstawiłem trzy takie kartki, dwie francuskie (kartka 1 i kartka 2) oraz jedną niemiecką (kartka 3).

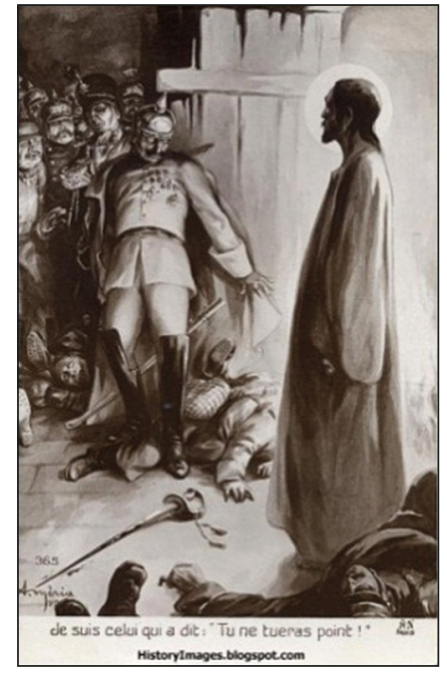

Kartka 1

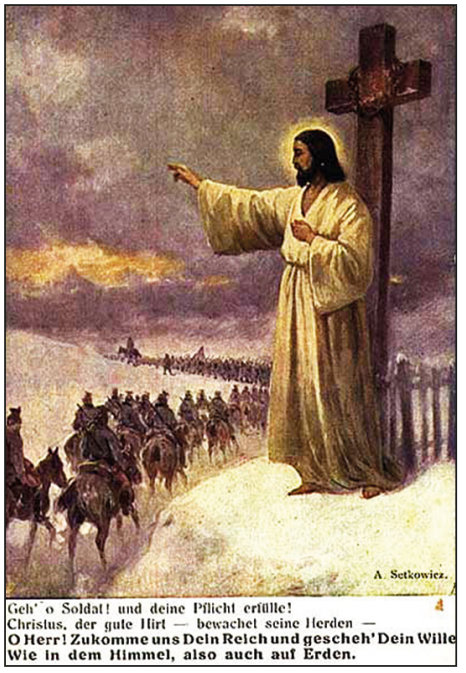

Kartka 3

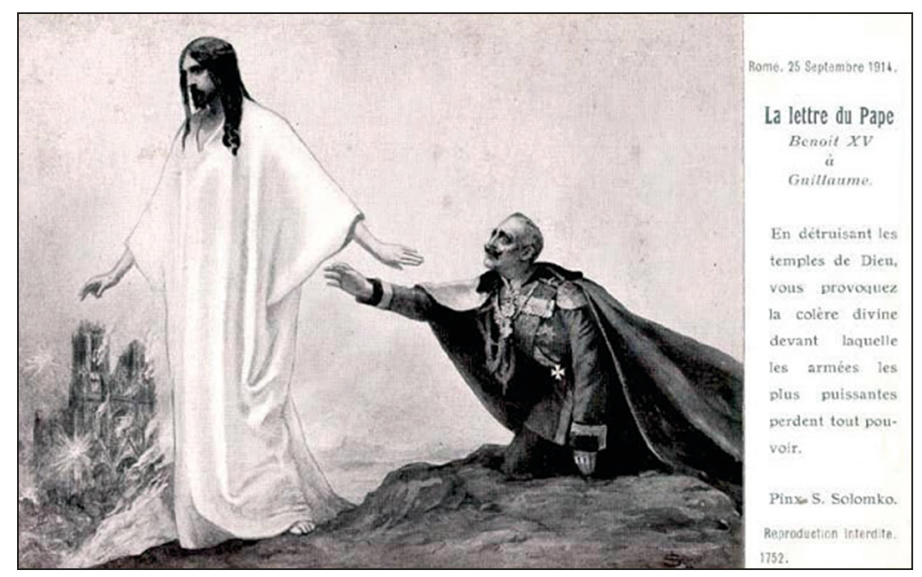

Kartka 2

Na pierwszej z kartek pocztowych Chrystus ukazuje się niemieckim żołnierzom. Na jej dole pojawia się napis po francusku: Je suis celui qui a dit: „Tu ne tueras point!” (Ja jestem tym, który powiedziat: „Nie będziesz zabijat”). Zastosowana tu strategia ma uzasadniać wojnę, w której Francja prowadzi działania zbrojne przeciw Niemcom i ich sojusznikom. Zbrodnie dokonane przez tych 
drugich sprawiają że w świecie ziemskim interweniować musi Chrystus. Sam obraz zbudowany jest na grze kontrastów. Z jednej strony mamy Jezusa otoczonego światłościa $\mathrm{z}$ drugiej zaś stłoczonych w kącie izby niemieckich żołnierzy, którzy z niedowierzaniem, ale też i z wyraźnym lękiem, przypatrują się Chrystusowi. Generał znajdujący się na przedzie spogląda na ofiary leżące na podłodze, zaczyna uświadamiać sobie ogrom okropieństw, których dopuścili się Niemcy. Ta manifestacja Chrystusa w ziemskim świecie pośrednio wydaje się nawiązywać do wydarzenia opisanego w Ewangeliach, kiedy to zmartwychwstały Jezus ukazał się swym zatrwożonym uczniom. W obu przypadkach boża interwencja następuje w okolicznościach utraty przez ludzi nadziei. Różnica tkwi w tym, że objawienie się Chrystusa uczniom miało radosny charakter. $\mathrm{W}$ omawianym przypadku Jezus pojawia się nie tylko, by napełnić nadzieją cierpiących na wojnie, ale przede wszystkim, aby przestrzec tych, którzy są oprawcami. Zastosowane w tym obrazie zabiegi metaforyczne miały swój określony cel. Zdają się nawiązywać do podziału poczynionego przez św. Augustyna na wojny sprawiedliwe i niesprawiedliwe. Francuzi uczestniczą w tej pierwszej. Stają zatem po stronie Chrystusa, który z powodu potworności zbrodni dokonywanych przez Niemców objawia się w ludzkim świecie. Narracja ta pojawia się także na drugiej z przedstawionych przeze mnie francuskich kartek pocztowych. W tym przypadku Chrystus opuszcza Niemców. Cesarz Wilhelm II Hohenzollern klęka, błagalnym gestem próbuje zatrzymać Jezusa. W tle widzimy zgliszcza kościoła, który przypomina paryską katedrę Notre-Dame.

Postać Chrystusa była wykorzystywana nie tylko w propagandzie francuskiej. Odwoływali się do niej także Niemcy. Widać to na trzeciej z zaprezentowanych powyżej kartek pocztowych. Na pierwszym planie pojawia się Chrystus, który błogosławi ruszających na wojnę żołnierzy. Walka, w której będą uczestniczyć, nie ma wyłącznie doczesnego charakteru, rozgrywa się także w wymiarze transcendentnym. Żołnierze stają się narzędziem Boga w ustanawianiu Jego Królestwa, w realizacji Jego woli. Co ciekawe, autor nie zdecydował się na umieszczenie postaci Chrystusa na polu bitewnym. Taki zabieg, przez swą znaczącą niespójność z nauczaniem Jezusa, okazałby się zapewne nieskuteczny. Dystans, jaki na omawianej kartce dzieli Chrystusa i żołnierzy, pomniejsza dane im przez niego błogosławieństwo.

W propagandzie wojennej motywy związane z Jezusem pojawiały się także w sposób pośredni. Dobrym tego przykładem jest plakat rozpowszechniany przez Amerykanów na Filipinach. Miał on nakłaniać do zakupu obligacji wojennych. Mimo że ówczesne Filipiny pozostawały de facto pod kontrolą protestanckich Stanów Zjednoczonych, to większość mieszkańców wysp stanowili katolicy. Ta struktura wyznaniowa była dziedzic- 
twem hiszpańskiej kolonizacji, jaka trwała tam od XVI w. Odniesienia do katolicyzmu są wyraźnie widoczne na poniższym plakacie (plakat 1). Na pierwszym planie mamy do czynienia z niemieckim żołnierzem krzyżującym żołnierza amerykańskiego. Na horyzoncie pojawia się amerykańska armia. Daje ona nadzieję na przerwanie tej męki. Przeraża też niemieckich oprawców, którzy na jej widok zaczynają uciekać. Funkcjonujący na plakacie motyw pasyjny, silnie zakorzeniony w katolicyzmie w ogóle, ze szczególną siłą musiał oddziaływać na Filipińczyków, gdyż miejscowe misteria towarzyszące obchodom wielkanocnym nierzadko przybierały tu bardzo spontaniczny i krwawy charakter.

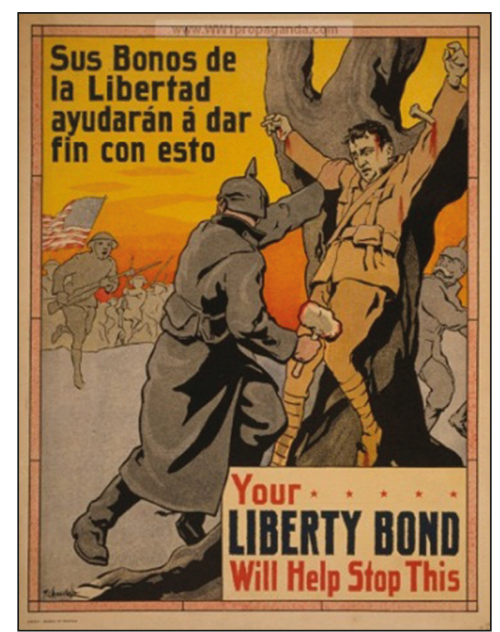

Plakat 1

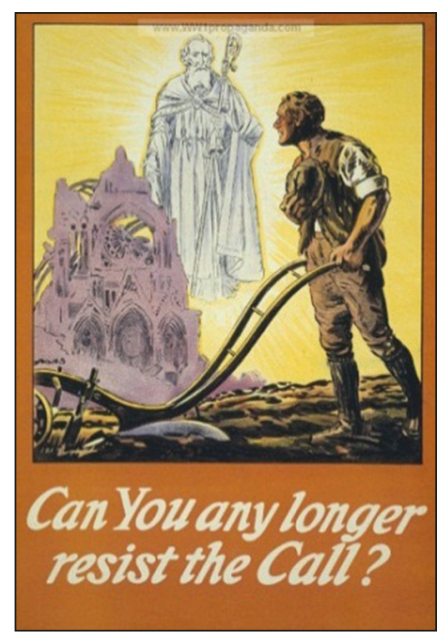

Plakat 2

W propagandzie wojennej odwoływano się nie tylko do postaci Chrystusa. Na plakatach pojawiali się także święci. Zachęcali do wstąpienia do wojska. Taka sytuacja przedstawiona jest na plakacie rekrutacyjnym (plakat 2) skierowanym do irlandzkich rolników. Na pierwszym planie widzimy chłopa, który przerywa oranie ziemi, gdy objawia mu się otoczony światłością św. Patryk. W tle obecna jest zniszczona katedra. Na dole widnieje napis: Can You longer resist the Call? (Czy jesteś w stanie opierać się dtużej wezwaniu?).

$\mathrm{Z}$ perspektywy twórców propagandy wojennej, Bóg wspierał jedną ze stron konfliktu, gdyż ta toczyła walkę w imię Dobra, brała udział w wojnie sprawiedliwej przeciw siłom Zła. Te siły Zła należało jednak upersonifikować. Postacią którą często wykorzystywano w tym celu pozostawał diabeł. Przykładem tego są dwa poniższe, satyryczne plakaty pochodzące ze Stanów Zjednoczonych, opublikowane w roku 1918. 


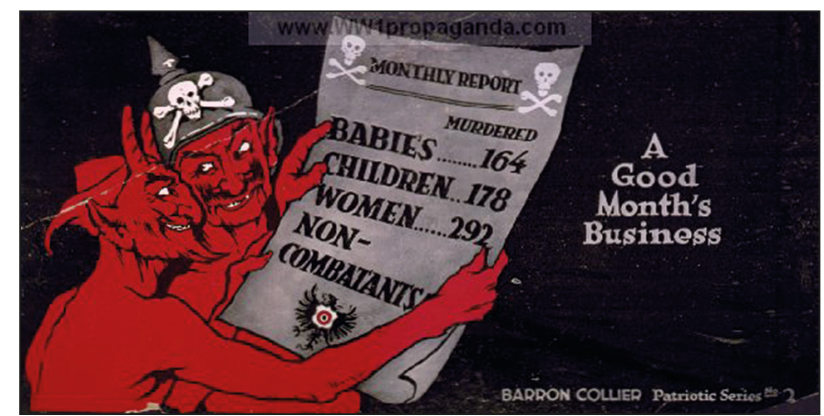

Plakat 3

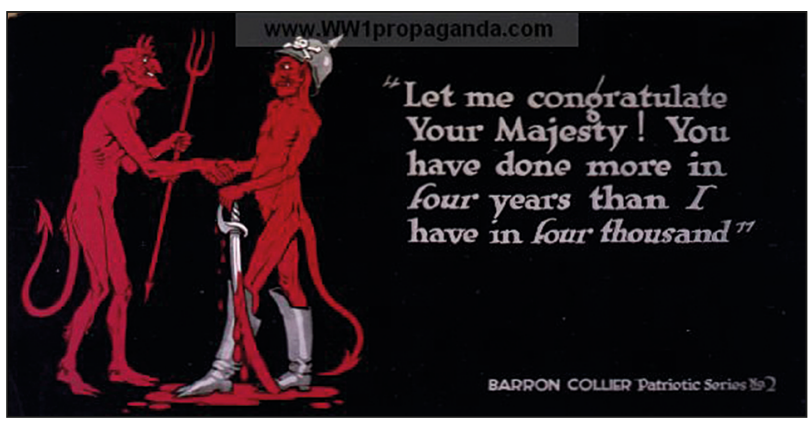

Plakat 4

Widać na nich dwie postacie: samego Szatana oraz Wilhelma II Hohenzollerna. Niemiecki cesarz przedstawiony został na nich jako diabeł. Na plakacie 3 na jego hełmie daje się zauważyć trupią czaszkę, na posterze 4 trzyma zaś w dłoniach zakrwawioną szablę. Autor narysował go także z diabelskim ogonem. Na plakacie 3 widnieje napis A Good Month's Business (Dobry miesiacc). Na liście, której oba diabły się przyglądają wypisana jest liczba poszczególnych ofiar, w tym niemowląt, dzieci, kobiet, cywili. Na drugim plakacie Szatan winszuje cesarzowi. Zwraca się do niego w następujących słowach: Let me congratulate Your Majesty! You have done more in four years than I have in four thousand (Pozwole sobie pogratulować Waszej Wysokości. W ciagu czterech latach zrobiłeś więcej niż ja w ciagu czterech tysiacleci). Wydaje się, że oba te plakaty nie tylko wyśmiewały przeciwnika, nie tylko budowały pewien dystans względem całego dramatu towarzyszącego działaniom zbrojnym, ale również broniły przed amerykańską opinią publiczną decyzji o udziale Stanów Zjednoczonych w wojnie.

Motyw sił diabelskich pojawiał się także $\mathrm{w}$ rosyjskiej propagandzie wojennej. Na jednym z analizowanych przeze mnie plakatów (plakat 5) 
do piekła przybywają cesarze: austriacki - Franciszek Józef I (na pierwszym planie) oraz niemiecki - Wilhelm II Hohenzollern (z tyłu). Sam obraz ma satyryczny charakter. W przeciwieństwie jednak do omówionych posterów amerykańskich, tutaj sytuacja wygląda nieco odmiennie. Ani cesarz austriacki, ani niemiecki nie są diabłami. Do piekła trafiają za swoje czyny. Do czekającego na nich Szatana zwracają się słowami: Prosimy o litość (zapisanymi na dole plakatu).

Znacznie bardziej złożony jest inny rosyjski plakat (plakat 6), na którym także pojawia się wątek diabelski. W odróżnieniu od wszystkich pozostałych nie ma on charakteru satyrycznego, w swej formie przypomina zaś stronę ze średniowiecznego dzieła poświęconego demonologii. Centralne miejsce zajmuje na nim Szatan, tutaj utożsamiony z cesarzem Niemiec. O jego diabolicznej naturze świadczą kopyta, ogon, sierść na ciele. Cechy te, które pierwotnie przypisywano greckiemu Panowi, w pierwszych wiekach naszej ery zostały użyte przez chrześcijan do budowy obrazu diabła. Piekielne pochodzenie cesarza wyrażono także za pomocą koloru czerwonego, symbolizującego krew, żar Gehenny. Wilhelm II

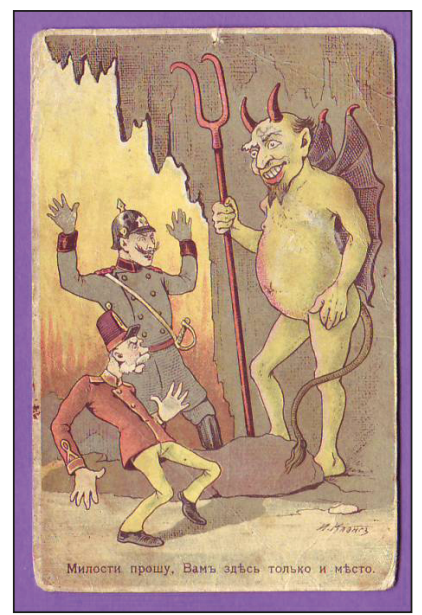

Plakat 5 przyodziany jest w zbroję, na której widnieje niemieckie godło, w obu swych rękach trzyma ludzkie czaszki. Ten wygląd cesarza, demoniczne przymioty, jakimi obdarzył go autor dzieła, skonfrontowane zostały ze stonowanym, zielono-żółtym tłem. Można na nim rozpoznać europejskie miasta, narysowane na modłę średniowieczna, otoczone rozkwitającymi łąkami. Na plakacie zostały wymienione ich nazwy. Miasto po lewej stronie to francuskie Reims, podczas I wojny światowej zbombardowane i niemal całkowicie zniszczone przez Niemców. Podobny los spotkał miasto znajdujące się w prawej części plakatu. Jest to belgijskie Leuven.

Wilhelm II, okryty zbroja, diabelski w swej istocie, burzy ten niemal idylliczny obraz Europy. Staje się ucieleśnieniem Zła, demonem krążącym po kontynencie i siejącym zniszczenie. Pod plakatem umieszczony został napis: Bpart рода человъческаzо (Wróg rodzaju ludzkiego).

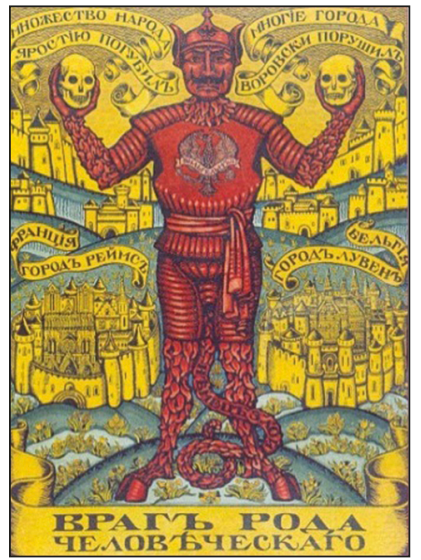

Plakat 6 
Założenie, zgodnie z którym wojna ma sprawiedliwy charakter i toczy się w imię Dobra oraz wiary, wyrażane było w ramach propagandy także i w inny sposób. Autorzy plakatów odwoływali się do historii. Znane wydarzenia z przeszłości umieszczali w odmiennym kontekście, w nowych okolicznościach. Narzucali cykliczną wizję czasu, zgodnie z którą ludzkość niekiedy musi mierzyć się z tymi samymi, choć $\mathrm{w}$ nieco odmienny sposób manifestującymi się, wyzwaniami. Istotną rolę odgrywały w tym przypadku kluczowe symbole czy słowa, pozwalające odbiorcy nadać szerszy sens zachodzącym na jego oczach wydarzeniom. Strategię tę zidentyfikowałem na dwóch poniższych posterach: amerykańskim (plakat 7) oraz rosyjskim (plakat 8).

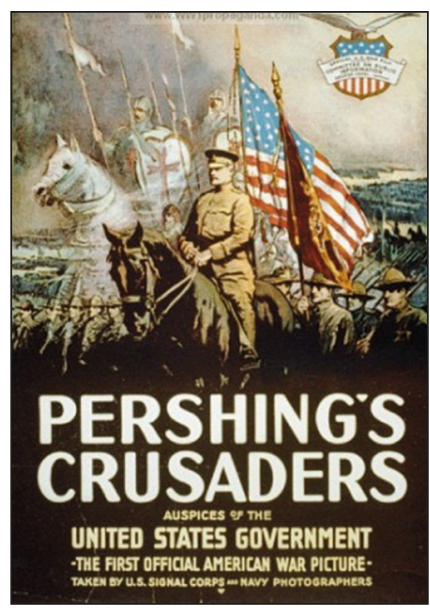

Plakat 7

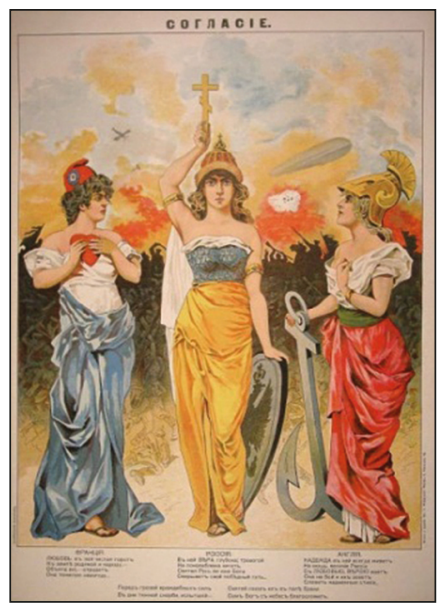

Plakat 8

Na plakacie 7 przedstawione zostały Amerykańskie Siły Ekspedycyjne, dowodzone przez generała Johna Pershinga. W tle widzimy rycerzy z charakterystycznymi czerwonymi krzyżami na tarczach. Wymarsz na wojnę do Europy porównano zatem do krucjaty. „Niewiernymi” okazały się w tym przypadku państwa centralne, burzące pokój na kontynencie. Na pierwszym planie plakatu 8 mamy natomiast przedstawione trzy kobiety, symbolizujące: Francję (po lewej), Anglię (po prawej) oraz Rosję (w środku). Pod nimi znajdują się następujące napisy: Miłość (Francja), Nadzieja (Anglia) oraz Wiara (Rosja). Zabieg ten można odczytać wprost. W tym przypadku plakat nawiązuje do trzech chrześcijańskich męczennic, znanych pod tymi właśnie imionami, zamęczonych po tym, jak ich matka nie wyrzekła się wiary w Chrystusa. Motyw ten często był 
Religijne odniesienia w propagandzie wojennej. Analiza zjawiska

podejmowany przez twórców ikon. Wskazany zabieg można interpretować też szerzej. Rosja pojawia się wówczas jako obrończyni prawosławnej wiary (kobieta ją symbolizująca - Matuszka Rosja - trzyma nad głową prawosławny krzyż). O ile w przeszłości chroniła ją przed Mongołami, katolickimi Polakami czy luterańskimi Szwedami, o tyle obecnie bój toczy się z innymi „niewiernymi” - reprezentowanymi przez państwa centralne.

\section{Konfrontacja z komunizmem}

Rok 1918 nie kończył zmagań wojennych w Rosji. Dał początek wojnie domowej, trwającej w niektórych rejonach nawet do roku 1924. Mimo że $\mathrm{w}$ konfrontacji tej brało udział wiele różnych stronnictw i grup, w tym słynna Czarna Armia Nestora Machno działająca na terenach dzisiejszej Ukrainy, to jednak dwiema głównymi stronami konfliktu byli tzw. biali, a więc zwolennicy ancien régime'u oraz „czerwoni”, przedstawiciele nowego porządku. W swojej analizie skoncentrowałem się na propagandzie wojennej właściwej dla tych pierwszych. Chociaż stosunek Karola Marksa i Fryderyka Engelsa do religii nie był jednoznacznie negatywny, zwracali bowiem uwagę, że czasami ucieleśnia ona gniew klasowy, to wśród rosyjskich komunistów dominował pogląd o społecznie regresywnym i politycznie reakcyjnym charakterze wiary. „Biali” natomiast dysponowali możliwością wykorzystania odniesień religijnych, także tych, które były powszechnie obecne podczas I wojny światowej. W owym czasie nawet jeszcze bardziej zyskiwały one na znaczeniu - konflikt toczył się przecież między ludźmi przywiązanymi do wiary i bezbożnymi bolszewikami. „Biali” mieli świadomość tego, że nie uda im się zwyciężyć rewolucjonistów, dopóki nie przekonają do siebie chłopów. Mostem między światem arystokracji a środowiskiem włościan okazała się wiara. Na użycie jakich strategii, motywów czy symboli decydowali się zatem „biali” w tej walce o dusze Rosjan?

Mobilizując ludzi do walki przeciw bolszewikom stosowano wypróbowany w czasie I wojny światowej zabieg. Przywoływano postać Chrystusa. Taka sytuacja jest przedstawiona na pierwszym plakacie z tego okresu, który poddałem analizie (plakat 9). Przedstawia on Jezusa wnoszącego krzyż na Golgotę. Jak niegdyś towarzyszyli mu rzymscy legioniści, tak teraz kroczą za nim bolszewiccy sołdaci. Chrystus ucieleśnia tu nie 
tylko wiarę chrześcijańska, ale i całą Rosję zmagającą się z komunizmem. Sam obraz został zbudowany na grze przeciwieństw. $Z$ jednej bowiem strony mamy na nim cierpiącego Chrystusa, z koroną cierniową na głowie, dźwigającego krzyż. Z drugiej zaś, rozbawiony orszak, w którym poszczególni żołnierze grają na harmonii, wymachują pieniędzmi, obejmują się z kobieta, niosącą $\mathrm{w}$ prawej dłoni butelkę alkoholu. Ich twarze wyrażają dobry nastrój, atmosferę zabawy. Na pierwszym planie, w prawym dolnym rogu autor plakatu umieścil postać Lwa Trockiego, jednego z czołowych przywódców bolszewickich podczas rewolucji październikowej, dowodzącego Armią Czerwoną w trakcie wojny domowej. Został on przedstawiony jako Judasz. Ten zabieg odczytywać można jako antysemicki. Opiera się na micie, zgodnie z którym to Żydzi są odpowiedzialni za śmierć Chrystusa. To żydowscy faryzeusze nakłonili bowiem Judasza, aby za trzydzieści srebrników zdradził swego nauczyciela. W czasach wojny domowej ów mit uległ rozwinięciu, łączył w sobie dawny antysemityzm, obecny w tradycji chrześcijańskiej, z nowym, kształtującym się w wieku XIX. Żydzi, tym razem już jako komuniści, szerząc ateizm zainteresowani byli upadkiem wiary. Pojawiała się zatem mityczna więź łącząca śmierć Chrystusa w przeszłości i agonię chrześcijaństwa (i Świętej Rusi) obecnie.

W opozycji do wesołej atmosfery panującej wśród żołnierzy pozostaje także sposób, w jaki autor plakatu przedstawił niebo. Na horyzoncie staje się ono ciemniejsze. Zabieg ten nawiązuje do opisu śmierci Chrystusa w Nowym Testamencie. W Ewangelii św. Marka możemy przeczytać: A gdy nadeszła godzina szósta, mrok ogarną cała ziemię aż do godziny dziewiatej (Mk. 15,33). W Ewangelii św. Łukasza wydarzenie to opisane jest natomiast w sposób następujący: Było już około godziny szóstej i mrok ogarnąt cała ziemię aż do godziny dziewiatej. Stońce się zaćmiło i zasłona przybytku rozdarła się przez środek (Łk. 23,44). Sam plakat nie skłania jednak do rezygnacji $\mathrm{z}$ walki. Wskazuje na to wiersz umieszczony na jego dole. Ostatnie jego wersy brzmią:

Верю я, что близок свет денницьы Сердие, жди! Я верю и молюсь!/ После тяжких дней Страстной Седмицьь/ Бог воскреснет, и воскреснет Pусь! [Przetłumaczyć to można tak:] Wierzę, że bliskie jest światło jutrzenki/ Serce, czeka! Wierze i btagam!/ Po tych trudnych dniach Wielkiego Tygodnial Bóg zmartwychwstanie, i zmartwychwstanie Ruś.

Wersy te dają nadzieję. Czas wojny domowej porównany został do dni, które dzielą śmierć Chrystusa na Golgocie od jego cudownego zmartwychwstania. 


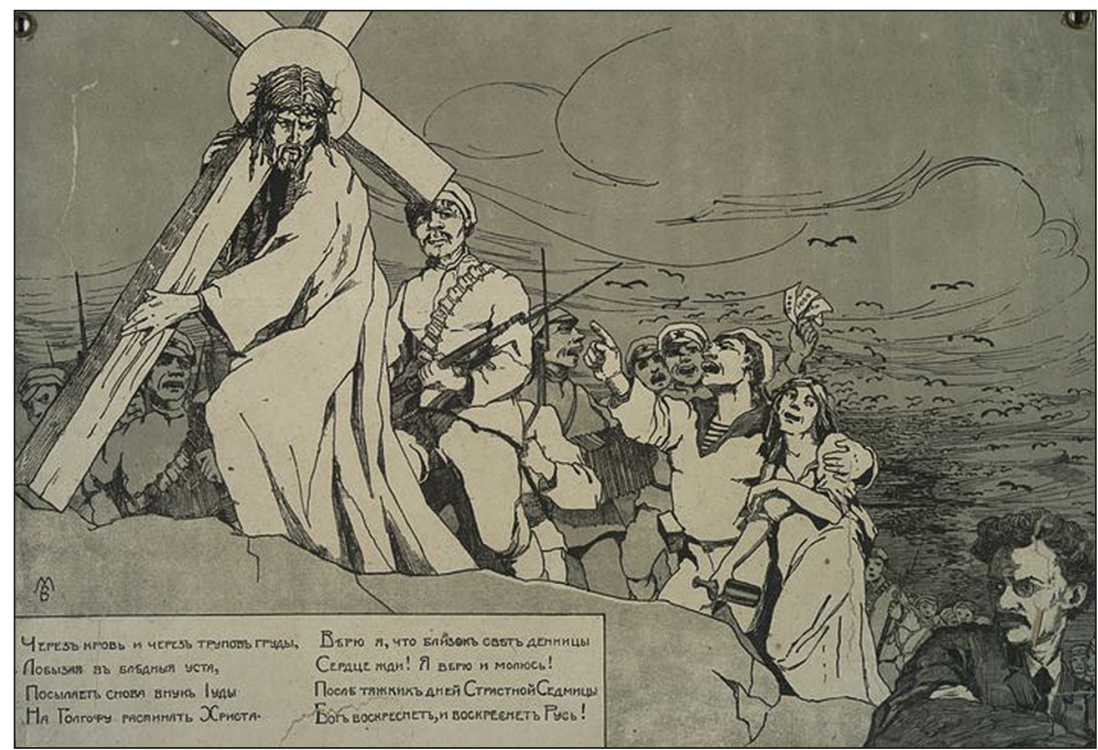

Plakat 9

Symbolika biblijna pojawiła się także na innym z analizowanych posterów (plakat 10). W sposób satyryczny przedstawiony został na nim rytuał złożenia ofiary nowemu Bogu, którym jest - zgodnie $\mathrm{z}$ widniejącym na posterze napisem - Internacjonalista. W kondukcie na szczyt świątyni, która swym wyglądem przypomina babilońskie zigguraty czy inne bliskowschodnie obiekty sakralne, uczestniczą od lewej- jako pierwszy Aleksander Kiereński, a następnie działacze komunistyczni: Mojżesz Urycki, Jakow Swierdłow, Grigorij Zinowjew, Anatolij Łunaczarski, Chrystian Rakowski, Włodzimierz Lenin, Lew Trocki, Lew Kamieniew oraz Karol Radek. W ofierze składana jest Matuszka Rosja, uosobieniem zaś Boga, owym Internacjonalista, jest Karol Marks. Na samym dole autor przedstawił trójkę rozbawionych żołnierzy. Można odnieść wrażenie, że plakat odwołuje się do tych fragmentów Biblii, które opisywały kult plemion pogańskich, $\mathrm{w}$ tym fenickiego Molocha. W ofierze bogom składano ofiary, które symbolizować miały dziewictwo, niewinność. Na opis tego kultu natrafiamy w Drugiej Księdze Królewskiej. Wskazuje się w niej na reformę religijną dokonaną przez Jozjasza. W Księdze tej stwierdza się, że ów władca

splugawit Palenisko-Zgroze w Dolinie Synów Hinnoma i już nikt odtąd nie przeprowadzat swego syna lub swojej córki przez ogień na cześć Molocha (2 Krl. 23: 10). 
W Księdze Jeremiasza natomiast Bóg takimi słowami opisuje prorokowi ów fenicki kult:

I zbudowali wyżyny Baala w dolinie Ben-Hinnom, by ofiarować swych synów i swoje córki ku czci Molocha. Nie poleciłem im tego ani Mi na myśl nie przyszło, by można czynić coś tak odrażajacego i doprowadzić Judę do grzechu (Jr. 32: 35).

Szczególną uwagę warto zwrócić na postaci uwzględnione w kondukcie. A. Kiereński, uczestnik rewolucji lutowej, premier Rządu Tymczasowego, z pewnym dystansem patrzy na to, co się dzieje, jakby czuł wstręt bądź lęk przed tym, w czym bierze udział. Ceremonii przewodniczy W. Lenin ubrany w czerwoną togę oraz L. Trocki dokonujący mordu ofiary. W przypadku niektórych postaci podkreślone zostało ich żydowskie pochodzenie. Zabiegu tego dokonano uwydatniając te cechy, które tradycyjnie przypisywano Semitom („orle nosy”), czy wyznawcom judaizmu (pejsy). Jedna $\mathrm{z}$ postaci, ta trzymająca $\mathrm{w}$ ręku worek z nadrukowaną na nim liczbą 30, symbolizuje Judasza.

Plakat przedstawia zatem rewolucję jako rytualny amok, orgiastyczny szał, w trakcie którego na ołtarzu nowego bóstwa zostaje złożona niewinna Matuszka Rosja. Sami Rosjanie, podburzani przez Żydów, biorą udział w tym krwawym rytuale (jak W. Lenin), podchodzą do niego z entuzjazmem (jak marynarz), czasami czerpiąc z tego korzyści (żołnierz z workiem) bądź z niepokojem uświadamiają sobie, do czego się przyczynili (A. Kiereński).

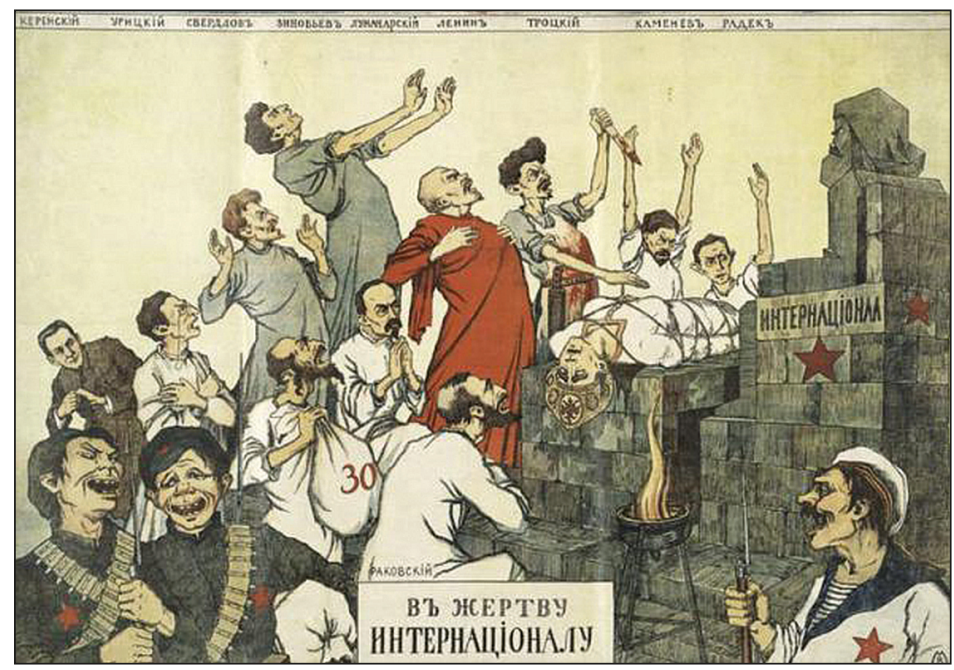

Plakat 10 
W ówczesnej propagandzie „białych” nie zabrakło także innych zabiegów, które zaobserwowałem wcześniej w przypadku plakatów pochodzących z I wojny światowej. Jedną ze strategii pozostawała personifikacja Zła, demonizacja przywódców komunistycznych. Przykładem tego jest plakat przedstawiony poniżej.

Sam poster ma satyryczny wydźwięk. Na samej górze widnieje napis: Mup u свободa в Coвdenuu, co przetłumaczyć można jako: Pokój $i$ wolność w Republice Rad. Centralne miejsce zajmuje na nim postać L. Trockiego, który został zaprezentowany jako Szatan gnębiący kraj. Czerwony kolor ciała symbolizuje z jednej strony jego przynależność do obozu bolszewików, z drugiej zaś jest to krew Rosjan. Demoniczny wygląd L. Trockiego podkreślony został określonymi zabiegami. Komunistycznego przywódcę zobrazowano jako monstrualnej wielkości potwora, który żywi się ludźmi. Dowodem tego jest krew spływająca po murach oraz czaszki, które zalega-

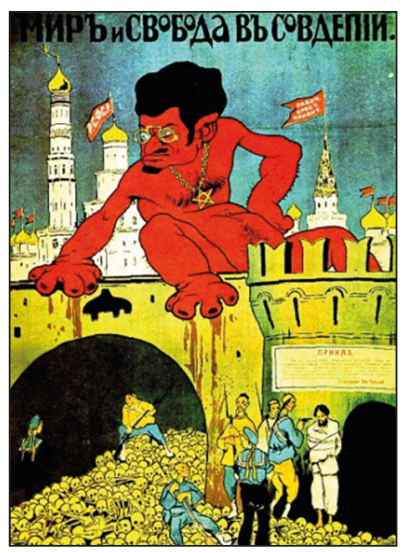

Plakat 11 ją u wejścia do miasta. Z kolei na szyi ma łańcuszek, na którym wisi pentagram. W tle widać prawosławne cerkwie. Brakuje na nich krzyży bądź są one połamane. Zamiast nich widzimy natomiast czerwone, komunistyczne flagi. Na samym dole plakatu, wśród czaszek porozrzucanych na ziemi, pojawiają się żołnierze i ich ofiara. Co ciekawe, przynajmniej dwóch z nich fizjonomicznie przypomina Azjatów z Dalekiego Wschodu. Wskazują na to skośne oczy, wąsy przystrzyżone na wzór chińskich mandarynów oraz charakterystyczne dla tego regionu nakrycia głowy. Ich ofiara, ku której wymierzają swoją broń, jest rosyjski chłop. Makabryczną atmosferę wzmacnia brunatny kolor nieba, tak jakby pociemniało ono bądź od samej obecności Szatana-Trockiego, bądź od podpaleń, pożarów wybuchających w mieście.

Omówione powyżej plakaty w większości miały charakter defensywny, w tym sensie, że koncentrowały się na wrogach „,białych”, prezentowały ich w niekorzystnym świetle. Oprócz tego istniała także propaganda, którą nazwałbym ofensywną. Symbolizujące „białych” postacie, bohaterzy, z którymi się utożsamiali, przedstawieni zostali na nich w sposób dynamiczny, najczęściej jako osoby walczące, cieszące się triumfem nad wrogiem. Widać to na dwóch poniższych plakatach. 


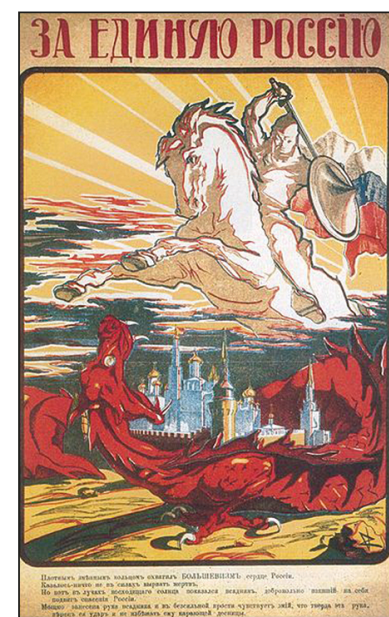

Plakat 12

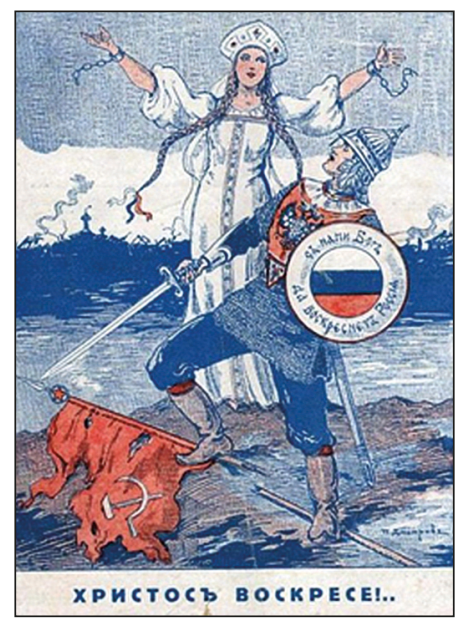

Plakat 13

Na obu znajdują się pewne odniesienia religijne. Plakat 12 odwołuje się do legendy o św. Jerzym, opowieści powszechnie znanej wśród prawosławnych chrześcijan. U góry widnieje napis: 3 a Единую Россию (Za jednq Rosję). Świety Jerzy, symbolizujący w tym przypadku Rosję, podobnie, jak na prawosławnych ikonach, toczy bój z czerwonym smokiem, oznaczajacym Zło, bolszewików. Z kolei na plakacie 13 widzimy na pierwszym planie rosyjskiego rycerza przełamującego drzewce, na którym owinięta jest poszarpana flaga bolszewików. Na tarczy wypisane ma $C$ ъ нами Богъ ( $Z$ nami jest Bóg) oraz Да воскреснет Россия (Tak zmartwychwstanie Rosja). Tuż za nim stoi kobieta, w tradycyjnym rosyjskim stroju ludowym, która symbolizuje zapewne Matuszkę Rosję. W tle widać zgliszcza, jakie zostały po wsiach i miastach, $w$ tym cerkwię ze złamanym krzyżem. Białe niebo, niebieski krajobraz w oddali oraz czerwony, bolszewcki sztandar przygnieciony noga rycerza układają się we flagę carskiej, przedrewolucyjnej Rosji. Na dole plakatu widnieje napis: Xpucmocb воскресе! (Chrystus zmartwychwstat!)

W roku 1919 działania zbrojne przeniosły się także na teren Polski. Komuniści zakładali, że uda im się rozniecić rewolucyjne nastroje w całej Europie, co miałoby prowadzić do upadku systemu kapitalistycznego. Podążając do Niemiec, a także dalej, do Francji i Wielkiej Brytanii, musieli wejść w konfrontację militarną z Polską. Interesujące jest to, jak wiele wątków, tak charakterystycznych dla plakatów tworzonych przez "białych”, pojawiało się $\mathrm{w}$ twórczości polskich autorów. Konflikt także starano się rozpatrywać $w$ kategoriach transcendentnych, jako wojnę między Złem (antychrześcijańskim bolszewizmem) a Dobrem (katolicką Polską). Przy- 
jęto, że Bóg poparł określoną stronę w tej walce, a późniejsze wydarzenia, w tym Cud nad Wisła, miały być tego dowodem.

Zgodnie z tytułem znajdującym się u dołu, na plakacie 14 przedstawiono wieś po najeździe bolszewików. Widzimy na nim całkowicie zniszczone budynki, walający się gruz, łunę pożaru gdzieś w oddali, wystającą spod kamieni rękę. W centralnym miejscu znajduje się jednak ołtarz, będący pozostałością kościoła. Przekaz ten jest jednoznaczny. Bolszewicy nie dość, że niszczą i grabia, jak wszyscy inni najeźdźcy, to jeszcze nie mają szacunku dla świętości. Nie bez powodu też bohaterem plakatu stała się polska wieś. Ówczesne władze mogły się obawiać, jak chłopi zareagują na komunistyczne hasła. Nowe państwo jeszcze nie okrzepło, bolszewicy sugerowali zaś, że będzie ono kontynuacją feudalnych porządków. Propaganda wojenna odwoływała się zatem do tradycyjnej wiary polskich chłopów, ich przywiązania do takich symboli, jak krzyż. Nawiązanie do pobożności ludowej znajduje się także na plakacie 15. Na samym jego dole widnieje napis: Kto w Boga wierzy, w obronie Ostrobramskiej, pod sztandar Orła i Pogoni! Żołnierz przedstawiony na plakacie chroni przed bolszewikiem nie tylko kobietę z dzieckiem, ale też i wiarę (w tym - Matkę Boską Ostrobramską).

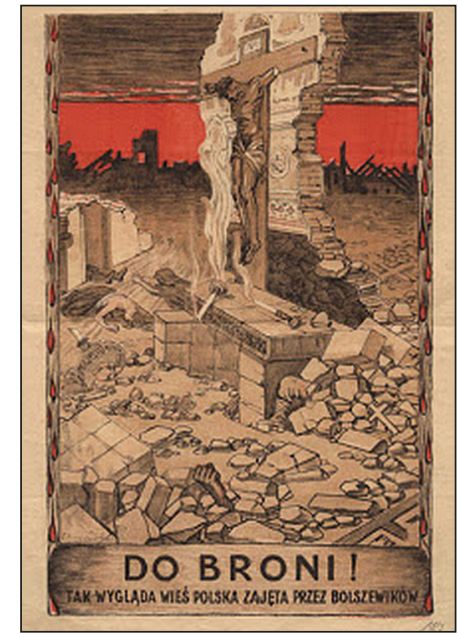

Plakat 14

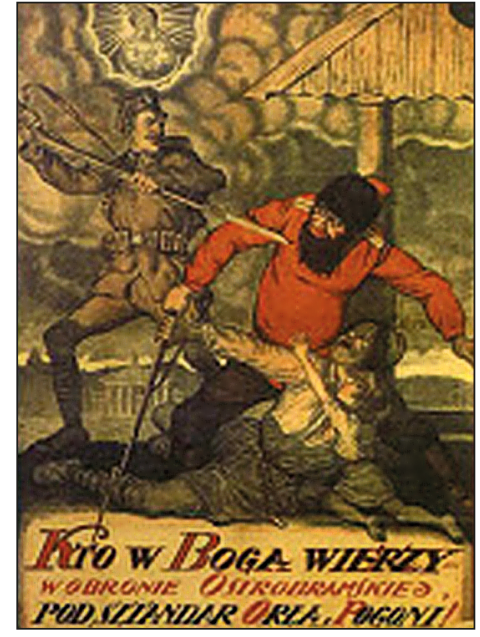

Plakat 15

Na ostatnim z analizowanych przeze mnie plakatów (plakat 16), powstałych $\mathrm{w}$ trakcie wojny polsko-bolszewickiej, mamy do czynienia ze znaną już strategią personifikacji Zła, demonizacji wroga. Polska propaganda sięgała $w$ tym przypadku do motywu wykorzystywanego przez stronnictwo „białych” w wojnie domowej w Rosji. 


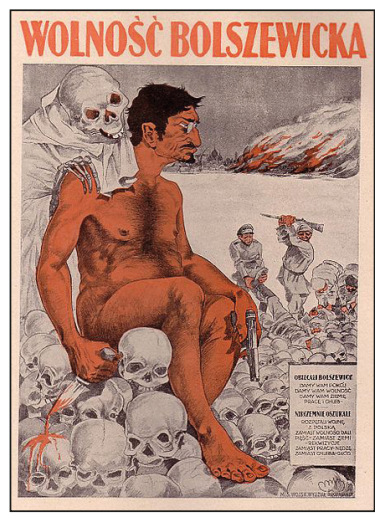

Plakat 16

Plakat przedstawia L. Trockiego jako diabła odpowiedzialnego za spustoszenia dokonywane przez bolszewików. Siedzi on na stosie czaszek. Widzimy, jak zza placów obejmuje go śmierć. W dłoniach trzyma nóż ociekający krwią oraz pistolet. W dole bolszewiccy żołnierze dobijają ludzi, okradają zmarłych. Zimowe tło przecina ogień trawiący pobliską wieś. Na prawym dolnym rogu plakatu, w zamieszczonej tam tabeli można przeczytać:

Obiecali Bolszewicy: Damy wam pokój. Damy wam wolność. Damy wam ziemię, pracę i chleb. Nikczemnie oszukali: rozpętali wojnę z Polską. Zamiast wolności dali pięść. Zamiast ziemi - rekwizycje. Zamiast pracy - nędzę. Zamiast chleba - głód.

\section{Druga wojna światowa}

Ostatnim konfliktem, który wziąłem pod uwagę w swych rozważaniach, była II wojna światowa. Mimo że w trakcie jej trwania w pełni rozwinięta była już możliwość, aby do celów agitacyjnych wykorzystywać inne środki oddziaływania, w tym chociażby film czy radio, to plakat dalej pozostawał w powszechnym użyciu. Analizując postery z tego okresu zaobserwowałem, że pojawiające się na nich odniesienia religijne są nie tylko różne od tych, które pozostawały typowe dla wcześniejszych konfliktów, ale w ogóle jest ich zdecydowanie mniej. Ich autorzy jedynie czasami umieszczali na swych plakatach świętych czy Chrystusa, explicite jednak rzadko nawiązywali do tematyki biblijnej czy do sztuki chrześcijańskiej. Gdyby przyjąć wąską definicję religii i ograniczyć się tylko do tych elementów bądź obrazów, które wprost nawiązują do sfery sacrum, to można byłoby uznać, że znaczna część działań propagandowych w czasie II wojny światowej pozostawała na swój sposób zsekularyzowana. W moim odczuciu jednak dało się zaobserwować pewne przemieszczenie tego, co D. Hervieu-Léger nazywa pierwiastkiem religijnym. Niektóre plakaty, które przyszło mi analizować zdawały się zawierać odniesienia religijne, choć trzeba tu zaznaczyć, że uległy one dekompozycji i już przekształcone umieszczane były $w$ kontekście pozbawionym zakorzenienia $\mathrm{w}$ sferze sacrum. Strategia ta cechowała przede wszystkim propagandę niemiecką. Pewnym przykładem $\mathrm{w}$ tym względzie jest plakat 17. 
Widnieje na nim wątek obecny już w propagandzie, znany chociażby z czasów wojny domowej w Rosji. Na plakacie pojawia się smok, którego w tradycji chrześcijańskiej utożsamia się z Szatanem. Źródeł tego porównania należy szukać w Apokalipsie św. Jana. Jeden z jej fragmentów mówi, że Szatan będzie próbował zgładzić Mesjasza:

I inny znak się ukazat na niebie: Oto wielki Smok barwy ognia, I mający siedem głów i dziesięć rogów - a na głowach jego siedem diademów. I ogon jego zmiata trzecia część gwiazd nieba: i rzucit je na ziemię. I staną Smok przed majaca rodzić Niewiasta, ażeby, skoro porodzi, pożreć jej dziecię. I porodziła Syna - Mężczyznę, który wszystkie narody będzie past rózga żelazna. I zostało po-

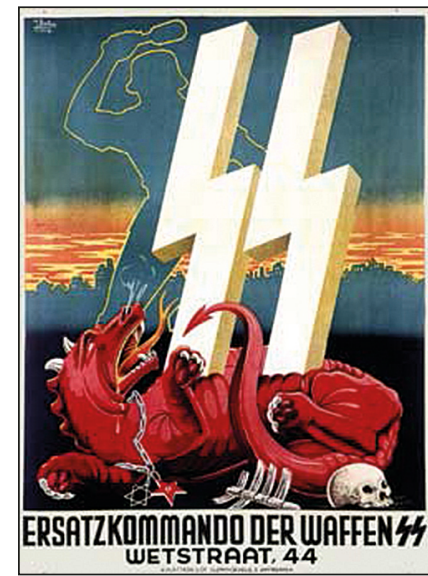

Plakat 17 rwane jej Dziecię do Boga i do Jego tronu (Ap. 12, 3-6).

W dalszej części swego przesłania Jan Ewangelista opisał walkę, jaką z Szatanem stoczy archanioł Michał:

I nastapiła walka na niebie: Michat i jego aniołowie mieli walczyć ze Smokiem. I wystapit do walki Smok $i$ jego aniołowie, ale nie przemógt, $i$ już się miejsce dla nich w niebie nie znalazło. I zostat stracony wielki Smok, Waż starodawny, który się zwie diabeł i szatan, zwodzacy cała zamieszkata ziemie, został stracony na ziemie, a $z$ nim straceni zostali jego aniołowie (Ap. 12: 7-9).

W tradycji chrześcijańskiej, zwłaszcza w przypadku Kościoła prawosławnego, bój ze Smokiem-Szatanem toczy na obrazach czy ikonach głównie św. Jerzy. Do tego wątku wprost odwoływała się propaganda „białych” w objętej wojną domową Rosji. W przypadku omawianego plakatu zastosowanie znajduje odmienna strategia. Nie występuje na nim żadna postać, którą można byłoby utożsamić z jakimkolwiek świętym. Smok pada pokonany przez symbol SS. Germańskie runy wbijają się w jego ciało. W tle widzimy zarys żołnierza, który przymierza się do ataku na bestię.

Smoka natomiast autor plakatu przedstawił w sposób, w jaki często pojawiał się on na chrześcijańskich obrazach czy ikonach. Budując wizerunek bestii uwzględnił dodatkowo pewne odniesienia polityczne, tropy, które pozwalają zrozumieć, w jaki sposób propaganda nazistowska próbowała mobilizować ludność do wstępowania do oddziałów SS czy wsparcia ich działań. Smok przypomina potwora znanego z rosyjskich posterów. Czerwony kolor jego łusek wprost symbolizuje wroga, jakim dla nazi- 
stowskich Niemiec byli komuniści, pośrednio zaś nawiązuje do barwy przypisywanej Szatanowi w tradycji chrześcijańskiej. Z szyi bestii zwisają pentagram oraz gwiazda Dawida. W ten sposób autor plakatu nie tylko starał się podkreślić demoniczną naturę komunizmu, ale również zdołał wyrazić pogląd powszechnie akceptowany wśród nazistów, że za triumf bolszewizmu w Rosji odpowiadają Żydzi. Wokół smoka leżą porozrzucane ludzkie kości, symbolizujące ofiary komunizmu. Konfrontacja między bestią a SS odbywa się w ponurej scenerii, uwydatnionej za pomocą łuny pożaru widniejącej na horyzoncie; scenerii, która w metaforyczny sposób oddaje ów półmrok apokaliptycznego starcia między Bogiem a Szatanem.

W przypadku analizowanego plakatu wyraźnie udało się zidentyfikować strategię zastosowaną przez propagandystów, zgodnie z którą konflikt między Trzecią Rzeszą a Związkiem Radzieckim nie ma wyłącznie charakteru doczesnego, ale pozostaje kolejną odsłoną odwiecznej walki. Autor tworzący poster zrezygnował jednak z odniesień stricte chrześcijańskich na rzecz symboliki germańskiej. Zabieg ten wielokrotnie był stosowany w niemieckiej propagandzie z czasów II wojny światowej. Przykładem tego są poniższe plakaty, które miały zachęcać ludność państw skandynawskich do poparcia Trzeciej Rzeszy (plakat 18), a także podjętej przez nią walki z komunizmem (plakaty 19 oraz 20).

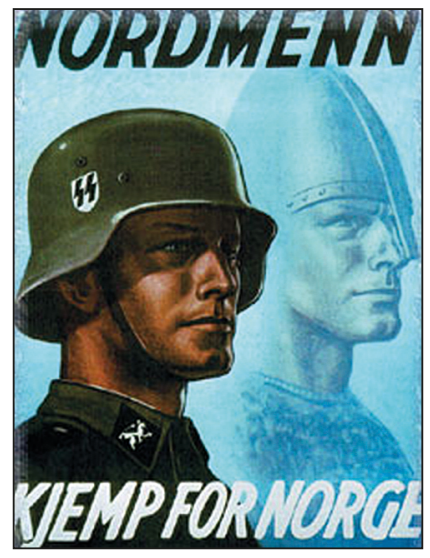

Plakat 18

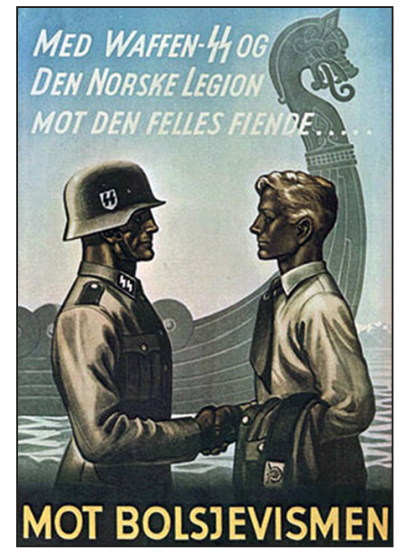

Plakat 19

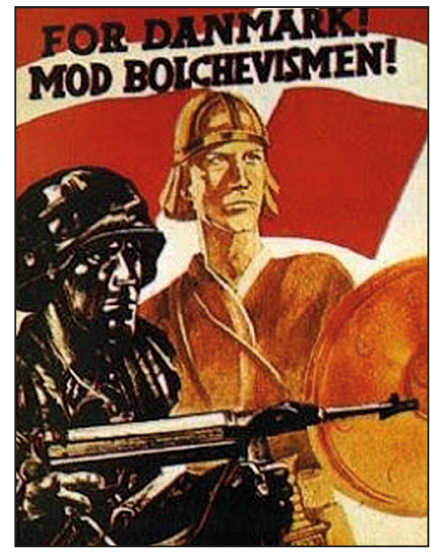

Plakat 20

Przyjmując definicję religii zaproponowaną przez D. Hervieu-Léger trzeba przyznać, że powyższe postery zawierają to, co autorka określała mianem pierwiastka religijnego. To założenie stanie się klarowniejsze, jeśli przyjrzymy się temu, w jaki sposób badaczka rozróżniała to, co religijne 
Religijne odniesienia w propagandzie wojennej. Analiza zjawiska

od tego, co niereligijne. W swoich rozważaniach przywołuje ona przykład dwóch rzemieślników zajmujących się wytwarzaniem skrzypiec. Pierwszy z nich, zapytany o tajemnicę starej metody wykonywania instrumentu, odpowiadając nie bierze pod uwagę żadnych odniesień metafizycznych. Stwierdza, że kluczem do wyprodukowania dobrych skrzypiec pozostaje lakier, jego dostosowanie do drewna, z którego zbudowany jest instrument. Drugi lutnik formułuje inną odpowiedź. Wyznaje:

Wybieram taki sposób wytwarzania, ponieważ dzięki niemu przyswajam sobie gesty i samego ducha, jakimi Stradivarius, Guarnerius czy Amati ożywiali swe skrzypce, którym nikt nigdy nie mógł dorównać w doskonałości... (cyt. za Hervieu-Léger 2007: 140).

W jego wypowiedzi daje się dostrzec obecność pierwiastka religijnego, odnoszącego się do samej pracy. Istnieje też „linia”, pewien „łańcuch powiązań" łączących lutnika z przeszłością. Przy uwzględnieniu takiej perspektywy trudno nie zauważyć pierwiastka religijnego tkwiącego $\mathrm{w}$ analizowanych plakatach. Na każdym z nich zidentyfikować można w tle elementy nawiązujące do Ducha dawnych czasów, do okresu, kiedy Skandynawowie byli budzącymi lęk wojownikami. Łączą one w sobie wojenną teraźniejszość z waleczną przeszłością plemion germańskich. Plakaty 18 oraz 20 sugeruja, że współczesnymi Wikingami są żołnierze walczący po stronie Trzeciej Rzeszy. Świadomie używam tutaj takiego właśnie określenia, gdyż chociażby na posterze 18 nieprzypadkowo pojawia się esesman (który wcale nie musi być Niemcem). Można odnieść wrażenie, że celem autorów było przedstawienie działań zbrojnych podejmowanych przez Trzecią Rzeszę jako aktu realizowanego w imię wszystkich ludów germańskich. Innymi słowy, plakaty miały namawiać do wstępowania do SS i walki po stronie Niemiec.

Warto tutaj zastanowić się nad tym, dlaczego nazistowscy propagandziści nie odwoływali się do wątków typowych dla tradycji chrześcijańskiej? Po I wojnie światowej nastąpił okres kształtowania się w Niemczech tego, co niektórzy badacze określają mianem „rewolucyjnego konserwatyzmu". W przeciwieństwie do tradycyjnego konserwatyzmu, który cechował się zachowawczościa, doktryna ta kładła nacisk na dynamizm, na niemal atawistyczną gwałtowność właściwą człowiekowi. Podkreślając ważność czynu, rewolucyjni konserwatyści wielbili walkę jako święto mocy, czas kształtowania woli, prawdziwy okres dojrzewania do męskości. Doktryna ta sakralizowała wojnę, mitologizowała przelewanie krwi, obronę honoru i ziemi. Zakładała, że za klęskę Niemiec odpowiedzialna jest mieszczańska małostkowość, filisterska próżność (Maciejewski 1991). 
Natchnieniem dla rewolucyjnych konserwatystów stał się romantyzm i właściwa mu fascynacja ludowością. Do kultywowania mocy lepiej nadawały się pogańskie wierzenia Germanów niż chrześcijaństwo, które wielbiło Chrystusa umierającego na krzyżu. Te odniesienia religijne odcisnęły piętno na kształtującym się po I wojnie światowej nazizmie, musiały być także obecne na plakatach tworzonych na użytek niemieckiej propagandy. $\mathrm{W}$ analizowanych posterach autorzy odwołali się do mitycznej jedności dawnych plemion germańskich, wspólnej im wyjątkowości i dzielności. Wskazane nawiązania wydają się szczególnie istotne, kiedy weźmiemy pod uwagę kontekst historyczny, w jakim były tworzone. Wojna ze Związkiem Radzieckim, będąca de facto walką ze Słowianami, stawała się okazją do rozbudzenia tej uśpionej przez chrześcijaństwo germańskiej siły.

W propagandzie czasów II wojny światowej całkowicie jednak nie lekceważono roli odniesień chrześcijańskich. Odwołania tego rodzaju były powszechne w plakatach amerykańskich. Przykładem tego są postery przedstawione poniżej.

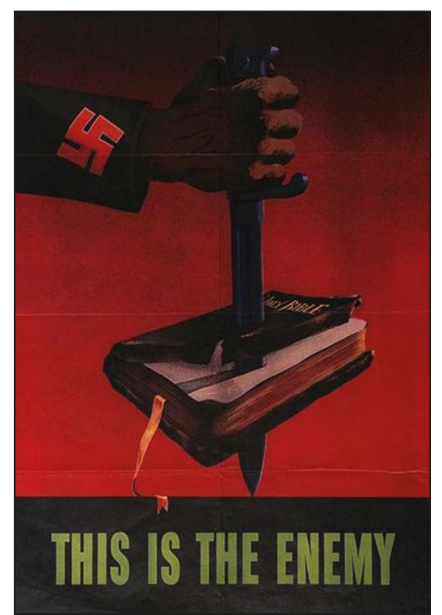

Plakat 21

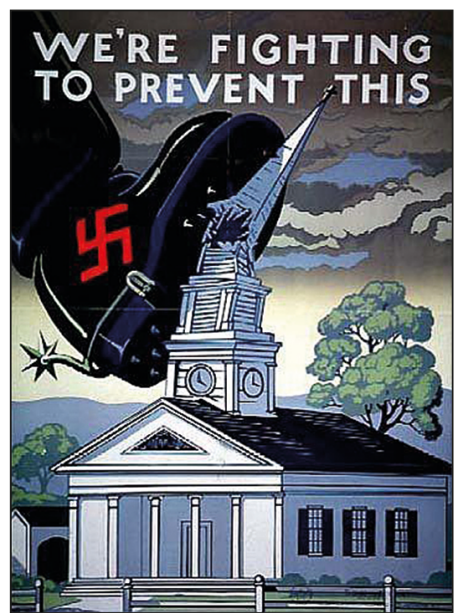

Plakat 22

Na plakacie 21 widać rękę wbijającą bagnet w Pismo Święte. Na jego dole jawi się następujący napis: This is the Enemy (To jest wróg). Na ubraniu, być może na fragmencie munduru, który widnieje na plakacie, obecna jest swastyka. Podobny motyw mamy na drugim $\mathrm{z}$ analizowanych tutaj rysunków. Na plakcie widzimy ogromny but z wymalowaną na nim swastyką, który burzy wieżyczkę typowego amerykańskiego kościoła protestanckiego. Niebo przykrywają ciemne chmury zwiastujące burzę. Szczególnie in- 
teresujące w przypadku obu plakatów jest to, że naziści nie zostali na nich $\mathrm{w}$ pełni spersonifikowani. Zamiast postaci ludzkich pojawiają się części ciała - ręka z bagnetem oraz noga w bucie, tak jakby wojna wkraczała w życie Amerykanów jako bezosobowa, ale jednak niszczycielska siła. Być może wpływ na to miał pewien dystans, jaki dzielił względnie spokojne Stany Zjednoczone od wojennej zawieruchy cechującej Europę.

Przekaz obu plakatów wydaje się jednoznaczny. Walka z Trzecią Rzeszą to przede wszystkim walka $\mathrm{w}$ imię chrześcijaństwa. To konflikt między Złem, reprezentowanym przez Niemcy i ich sojuszników, oraz Dobrem, czyli alianatmi. Po Pearl Harbor, Amerykańscy propagandziści musieli przekonać opinię publiczna, że istotna jest nie tylko konfrontacja z japońskim zagrożeniem, ale również wsparcie sojuszników na starym kontynencie. Innymi słowy, zobligowani byli do przełamania tradycyjnie izolacjonistycznych i antyeuropejskich nastrojów obecnych w społeczeństwie. Temu wyzwaniu odpowiada w szczególności plakat 22. Sugeruje on, że wraz z rosnącą potęgą militarną Trzeciej Rzeszy, walka może przenieść się na terytorium Stanów Zjednoczonych. Nie dziwi zatem, że w górnej części tego posteru widnieje napis: We're fighting to prevent this (Walczymy, aby temu zapobiec).

Odniesienia religijne pojawiały się także na amerykańskich plakatach rekrutacyjnych. Ich celem było zachęcenie młodych mężczyzn do tego, aby wstępowali do armii. Interesującą strategię propagandową nawiązująca do wątków religijnych, daje się dostrzec na plakacie 23.

Przedstawiono na nim afroamerykańskiego boksera Joe Louis'a w żołnierskim mundurze. Na dole zacytowane zostały jego słowa: We're going to do our part... and we'll win because we're on God's side (Zamierzamy zrobić, co swoje... i wygramy, bo jesteśmy po stronie Boga). Wydaje się, że nieprzypadkowo Joe Louis mówi w pierwszej osobie liczby mnogiej. Plakat skierowany jest do innych młodych Afroamerykanów, którzy mogli postrzegać II wojnę światową jako konflikt rozgrywający się między białymi. W jego konstrukcji użyte zostały jednak dwa "haczyki”, które miały ich zwabić, sprawić, że zdecydują się wesprzeć Stany Zjednoczone $\mathrm{w}$ walce $\mathrm{z}$ państwami Osi.

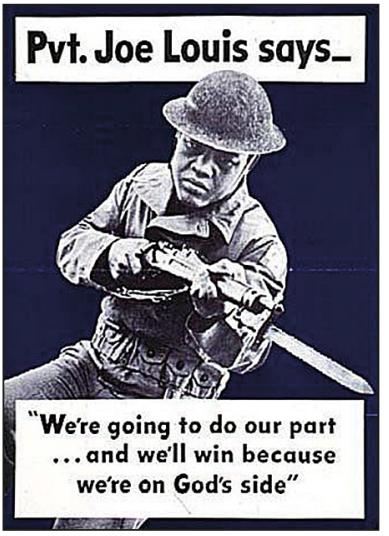

Plakat 23 Pierwszy z nich to sam Joe Louis, uosabiający sukces w środowisku Afroamerykanów. Drugim zaś pozostaje odwołanie się do wiary. Społeczność 
afroamerykańska była wówczas (i obecnie również jest) społecznością bardzo religijną. Stąd słowa, że „wygramy, bo jesteśmy po stronie Boga” musiały silnie oddziaływać na jej reprezentantów. Świadczyły dodatkowo, że konflikt rozgrywa się nie tyle między białymi ludźmi, ile przede wszystkim między Dobrem a Złem.

\section{Podsumowanie}

Z perspektywy socjologicznej propaganda wojenna nie jest jedynie formą manipulacji czy sposobem mobilizacji społecznej. Propaganda nie tylko bowiem ukierunkowuje, ale również odzwierciedla emocje tkwiące w społeczeństwie. Oddaje ducha czasów. Podejmując się analizy plakatów i kart pocztowych z obu wojen, zakładałem, że różnice, jakie przyjdzie mi zaobserwować, nie będą zbyt duże. W końcu oba konflikty dzieliło raptem dwadzieścia lat. Moje założenie okazało się błędne. W ciągu tych dwóch dekad podejście do propagandy uległo całkowitej zmianie. Owego zjawiska nie należy ograniczać wyłącznie do transformacji technik, sposobów wywierania wpływu na ludzi. Rozdźwięk między działaniami propagandowymi właściwymi dla I i II wojny światowej odzwierciedla szersze przemiany społeczne, które zaszły w tym czasie. Procesy te zyskują na wyrazistości niejako ex post, dopiero wówczas, gdy jesteśmy w stanie nadać im pewien kierunek. Tym bardziej zasadne staje się zatem, aby to na nich skoncentrowała się nasza uwaga.

W działaniach propagandowych typowych dla I wojny światowej odwołania do symboliki i tematyki religijnej były liczne. Dzięki temu sam konflikt zyskał szerszą perspektywę. Wojna stawała się kolejną odsłoną odwiecznej walki między Dobrem a Złem. Propaganda wprost nawiązywała do chrześcijańskiej eschatologii. Świat doczesny stał się miejscem manifestacji istot transcendentnych - Chrystusa i Szatana. Na analizowanych plakatach i kartkach pocztowych uwidoczniły się rozmaite zabiegi, które próbowały oddać tę eschatologiczną wizję. Różniły się one w zależności od tego, czy służyły dyskredytacji wroga, czy też konstrukcji obrazu własnej zbiorowości. Przeciwnika pokazywano jako reprezentanta piekieł. Stąd na plakatach pojawiał się on jako diabeł, demon lub smok. Obraz wroga budowano także na podstawie przypisywanych mu zachowań. Na posterach widzimy zatem bestialstwo orszaku prowadzącego Chrystusa na Golgotę. Wróg nie ma też poszanowania dla świętości, niszczy wiarę 
i związane z nią miejsca. Jest niczym apokaliptyczna Bestia przynosząca zagładę. W inny sposób konstruowano obraz własnej zbiorowości. Po jej stronie stoi nie tylko Chrystus, ale też i święci. Walka zyskiwała tym samym uzasadnienie, stawała się starciem w obronie wiary i Dobra. Ta polaryzacja, przejawiająca się $w$ plakatach właściwych dla I wojny światowej (oraz dla wojny domowej w Rosji i wojny polsko-bolszewickiej), służyła oczywiście określonemu celowi - dehumanizacji wroga.

To wzajemne przenikanie się dwóch wymiarów, transcendentnego i doczesnego, odzwierciedla pewien rozdźwięk typowy dla ówczesnej Europy. Jest to kontynent kroczący drogą uprzemysłowienia, pokładający nadzieję $w$ nauce, odrzucający obskurantyzm minionych epok. Religijne odniesienia obecne $\mathrm{w}$ propagandzie wydają się $\mathrm{w}$ tej sytuacji niedorzeczne. Tym bardziej skłaniają zatem do pewnych przemyśleń. Mimo wielu osiągnięć, zwłaszcza w sferze techniki, ówczesny europejski Rozum zdawał się być przesiąknięty tradycyjnym Duchem. Pełna ekspresja tego związku nastąpiła dopiero podczas wojny, gdy owo racjonalne myślenie kapitulowało na rzecz mitów, religijnej symboliki i tematyki. Europejczycy zdawali się nie być świadomi sił, które wyzwolili wkraczając na drogę modernizacji. Te siły trzeba było $w$ rezultacie ukazać odwołując się do znanych i zakorzenionych w religii archetypów. Wspomniane zjawisko skłania do sformułowania bardziej uniwersalnego wniosku. Być może nigdy nie jesteśmy tak ucywilizowani, za jakich chcemy uchodzić, a mur dzielący nasz świat od barbarzyństwa pozostaje bardzo kruchy.

Religijne odniesienia rzadziej pojawiały się $\mathrm{w}$ działaniach propagandowych typowych dla II wojny światowej. Za interesujący przedmiot analizy należy uznać w tym przypadku plakaty nazistowskie. Nawiązywały one do czegoś bardziej pierwotnego niż religia, do tego, co dziś wielu socjologów określa mianem duchowości. Duchowość pozostaje niedefiniowalna. Nie wpisuje się w wąskie granice wyznaczone przez systemy religijne. Wyłania się wprost z ludzkiej nieświadomości. Nazistowska propaganda, dostrzegając dysfunkcjonalność religii, z jej normami i moralizowaniem, koncentrowała się na zakorzenionej $\mathrm{w}$ germańskich wierzeniach duchowości. Stała się ona źródłem atawistycznej witalności, tej nieujarzmionej i brutalnej mocy, którą należało wskrzesić w niemieckim żołnierzu. Całkowicie odmiennie wyglądały amerykańskie plakaty propagandowe. Mimo iż pojawiały się na nich odniesienia religijne, to nie miały one charakteru transcendentnego. Na posterach widniały niszczone przez wroga kościoły. Do walki wzywali też sami żołnierze sugerując, że bój toczy się w imię Boga i Dobra. 
Podsumowując, te dwadzieścia lat, jakie minęło od zakończenia I wojny światowej, odcisnęło swe piętno na działaniach propagandowych. Odniesienia religijne pojawiały się na plakatach zdecydowanie rzadziej. Propaganda uległa sekularyzacji. Paradoksalnie, stała się ona pewnym probierzem zmian, które społeczeństwa w pełni zaczęły sobie uświadamiać dopiero po II wojnie światowej.

\section{Bibliografia}

Berger, P., ([1967] 2005), Święty baldachim. Elementy socjologicznej teorii religii. Kraków: Zakład Wydawniczy Nomos.

Berger, P., (1971), La religion dans la conscience modern. Essai d'analysa culturelle. Paris: Centurion. Beyer, P., (2005), Religia i globalizacja. Kraków: Zakład Wydawniczy Nomos.

Casanova, J., ([1994] 2005), Religie publiczne w nowoczesnym świecie. Kraków: Zakład Wydawniczy Nomos.

Corm, G., (2007), Religia i polityka w XXI wieku. Warszawa: Wydawnictwo Akademickie Dialog.

Dobbelaere, K., ([1974] 2003), Socjologiczna analiza definicji religii, [w:] Socjologia religii. Antologia tekstów, red. W. Piwowarski. Kraków: Zakład Wydawniczy Nomos.

Dobbelaere, K., (2008), Sekularyzacja. Trzy poziomy analizy. Kraków: Zakład Wydawniczy Nomos.

Durkheim, E., ([1912] 1990), Elementarne formy życia religijnego: system totemiczny w Australii. Warszawa: PWN.

Habermas, J., (2012), Między naturalizmem a religia. Warszawa: PWN.

Hervieu-Léger, D., ([1993] 2007), Religia jako pamięć. Kraków: Zakład Wydawniczy Nomos.

Hobbes, T., ([1651] 2005), Lewiatan. Warszawa: Wydawnictwo Aletheia.

Kepel, G., (2010), Zemsta Boga. Warszawa: Wydawnictwo Krytyki Politycznej.

Luhmann, N., ([1982] 2007), Funkcja religii. Kraków: Zakład Wydawniczy Nomos.

Maciejewski, M., (1991), Doktryna rewolucyjnego konserwatyzmu wobec narodowego socjalizmu 1921-1945. Wrocław: Wydawnictwo Uniwersytetu Wrocławskiego.

Pismo Święte Starego i Nowego Testamentu (1990). Poznań-Warszawa: Wydawnictwo Pallottinum.

Weber, M., ([1922] 2002), Gospodarka i Społeczeństwo. Warszawa: PWN.

Yinger, J.M., (1957), Religion, Society, and the Individual. New York: MacMillan Company.

\section{Spis kartek pocztowych}

Kartka 1

Źródło: http://historyimages.blogspot.com/2012/07/french-ww1-propaganda-posters.html

Kartka 2

Źródło: http://historyimages.blogspot.com/2012/07/french-ww1-propaganda-posters.html 
Religijne odniesienia w propagandzie wojennej. Analiza zjawiska

Kartka 3

Źródło: http://historyimages.blogspot.com/2012/07/rare-german-ww1-propaganda-posters. html

\section{Informacje na temat wykorzystanych w pracy plakatów}

\section{Plakat 1}

Autor: F.C. Amorsolo, 1917

Tytuł: Your Liberty Bond. Will Help Stop This

Źródło: http://en.wikipedia.org/wiki/File:Your_Liberty_Bond_will_help_stop_this_Crisco_ restoration.jpg

\section{Plakat 2}

Autor: nieustalony, 1915

Wydawca: McCaw, Stevenson and Orr Ltd, Dublin and Belfast

Tytuł: Can You longer resist the Call? (Czy jesteś w stanie opierać się dłużej wezwaniu?)

Źródło: http://www.ww1propaganda.com/ww1-poster/can-you-any-longer-resist-call

\section{Plakat 3}

Autor: nieustalony, 1918

Tytut: A Good Month's Business (Dobry miesiac)

Źródło: http://www.ww1propaganda.com/ww1-poster/good-months-business

\section{Plakat 4}

Autor: nieustalony, ok. 1918

Tytuł: Let me congratulate Your Majesty! You have done more in four years than I have in four thousand (Pozwole sobie pogratulować Waszej Wysokości. W ciagu czterech latach zrobiłeś więcej niż ja w ciagu czterech tysiacleci)

Źródło: http://www.ww1propaganda.com/ww1-poster/let-me-congratulate-your-majestyyou-have-done-more-four-years-i-have-four-thousand

\section{Plakat 5}

Autor: nieustalony, ok. 1915-1918

Tytuł: Prosimy o litość

Źródło: http://historyimages.blogspot.com/2012/07/russian-ww1-propaganda-posters.html

\section{Plakat 6}

Autor: nieustalony, ok. 1915-1918

Tytuł: Врагъ рода человъческаго (Wróg rodzaju ludzkiego)

Źródło: http://historyimages.blogspot.com/2012/07/russian-ww1-propaganda-posters.html

\section{Plakat 7}

Autor: plakat filmowy wykonano dla US Army. Signal Corps, 1918

Tytuł: Pershing's Crusaders

Źródło: http://www.ww1propaganda.com/ww1-poster/pershings-crusaders-auspices-united -states-government 


\section{Plakat 8}

Autor: nieustalony, Rosja, 1914

Tytuł: Cozласuе (Zgoda)

Źródło: http://en.wikipedia.org/wiki/File:Triple_Entente.jpg

\section{Plakat 9}

Autor: nieustalony, ok. 1918-1920

Tytuł: nieustalony

Źródło: http://ibrest.com/forum/?t=189

\section{Plakat 10}

Autor: nieustalony, ok. 1918-1920

Tytuł: Internacjonalista

Źródło: http://ibrest.com/forum/?t=189

\section{Plakat 11}

Autor: nieustalony, ok. 1918-1920

Tytuł: Мир и свобода в Совдепии (Pokój i wolność w Republice Rad)

Źródło: http://ru.wikipedia.org/wiki/Файл:Мир_и_свобода_в_совдепии._Троцкийюю. Пиакат_Харьковского_ОСВАГа,_1919.jpg

\section{Plakat 12}

Autor: nieustalony, ok. 1918-1920

Tytuł: 3а Единую Россию (Za jedna Rosje)

Źródło: http://commons.wikimedia.org/wiki/File:Beloe_Delo_1.jpg?uselang=ru

\section{Plakat 13}

Autor: nieustalony, ok. 1918-1920

Tytuł: Xpuстось воскресе! (Chrystus zmartwychwstał!)

Źródło: http://commons.wikimedia.org/wiki/File:Thecristisrizenoldrussiancivilwarposter. jpg

\section{Plakat 14}

Autor: Eugeniusz Nieczuja-Urbański, 1920

Tytuł: Do broni!

Źródło: http://paczemoj.blogspot.com/2008/02/polish-soviet-war-poster.html

\section{Plakat 15}

Autor: nieustalony, 1920

Tytuł: Kto w Boga wierzy, w obronie Ostrobramskiej, pod sztandar Orła i Pogoni!

Źródło: http://www.digitalpostercollection.com/propaganda/1919-1921-polish-soviet-war/ poland

\section{Plakat 16}

Autor: „mjk”, Polska, 1920

Tytuł: Wolność bolszewicka

Źródło: http://pl.wikipedia.org/wiki/Plik:Leon_Trotsky.JPG 


\section{Plakat 17}

Autor: nieustalony, 1940-1944(?)

Tytuł: Ersatzkommando der Waffen SS

Źródło: http://propaganda-art.tumblr.com/post/12605963699/ersatzkommando-waffen-ss

\section{Plakat 18}

Autor: nieustalony, ok. 1941-1943

Tytuł: Nordmenn Kjemp for Norge

Źródło: http://chumpfish3.blogspot.com/2008/04/kjemp-for-norge.html

\section{Plakat 19}

Autor: nieustalony, ok. 1941-1943

Tytul: Mot bolsjevismen

Źródło: http://www.soldat.com/Kunst\%20recruiting\%20posters.htm

\section{Plakat 20}

Autor: nieustalony, ok. 1941-1943

Tytuł: For Danmark! Mod bolchevismen!

Źródło: http://www.soldat.com/Kunst\%20recruiting\%20posters.htm

\section{Plakat 21}

Autor: nieustalony, ok. 1941

Tytul: This is the Enemy (To jest wróg)

Źródło: http://www.toptenz.net/top-10-wwii-propaganda-posters.php

\section{Plakat 22}

Autor: nieustalony, ok. 1941

Tytuł: We're fighting to prevent this (Walczymy, aby temu zapobiec)

Źródło: http://www.archives.gov/exhibits/powers_of_persuasion/warning/images_html/fi ghting_to_prevent.html

\section{Plakat 23}

Autor: United States Office of Facts and Figures, 1942

Tytuł: Pvt. Joe Louis says... "We're going to do our part... and we'll win because we're on God's side" („Zamierzamy zrobić, co swoje... i wygramy, bo jesteśmy po stronie Boga").

Źródło: http://en.wikipedia.org/wiki/File:Poster-Joe-Louis.jpg 